\title{
PREPARATION AND CHARACTERIZATION OF Ti-12Mo/x $\mathrm{Al}_{2} \mathrm{O}_{3}$ NANO-COMPOSITES FOR AEROSPACE APPLICATIONS
}

\author{
El-Tantawy, A. E. ${ }^{*} ;$; Yehia, H. M. ${ }^{*}$; El-Kady, O. ${ }^{\dagger}$ and Ghayad, I. M. ${ }^{\dagger}$ \\ * Department of Production Technology, Faculty of Industrial Education, Helwan University, Cairo, Egypt. \\ ${ }^{*}$ Central Metallurgical Research and Development Institute (CMRDI), P.O. Box 87, Helwan, Cairo, Egypt. \\ *Corresponding author: eng.ahmedeltantawy@yahoo.com, Tel: +2 01200966138.
}

\begin{abstract}
Titanium powder is reinforced with $12 \mathrm{wt} . \%$ molybdenum powder, and then the mixed Ti-12\%Mo matrix composite powder is reinforced with 5, 10, and 15 wt. \% nano $\mathrm{Al}_{2} \mathrm{O}_{3}$ by the mechanical milling for $24 \mathrm{hr}$. The mixed nano-composite powders were cold compacted under $600 \mathrm{MPa}$, then sintered at $1450^{\circ} \mathrm{C}$ for $90 \mathrm{~min}$. The microstructure and chemical composition of the Ti- $12 \mathrm{Mo} / \mathrm{Al}_{2} \mathrm{O}_{3}$ powders, as well as the fabricated composites, were investigated by both SEM and X-ray diffraction. It has been observed form the SEM studies of the sintered samples that the $\mathrm{Al}_{2} \mathrm{O}_{3}$ and Mo particles were homogeneously distributed all over the Ti matrix. All the composites were evaluated by measuring their density, hardness, and wear resistance. The results revealed that the addition of $12 \mathrm{wt}$. \% Mo to pure titanium improves its density due to its high density over than that of the $\mathrm{Ti}$ and the good adhesion between them, while the addition of $\mathrm{Al}_{2} \mathrm{O}_{3}$ decreases the density of the Ti-12Mo nano-composite. Not only the density of the Ti was improved by the addition of Mo, but also the hardness and wear resistance were also increased. Regardless of the decreasing in the density of Ti-12Mo nano-composite by increasing the $\mathrm{Al}_{2} \mathrm{O}_{3} \mathrm{wt}$. \%, the hardness and wear resistance were improved up to 5 wt. $\% \mathrm{Al}_{2} \mathrm{O}_{3}$.
\end{abstract}

Keywords: Powder Metallurgy; Titanium Matrix Nano-Composites; Hardness; Wear Rate; Aerospace Applications.

\section{INTRODUCTION}

Aerospace systems and performance-enhancing automobiles involve materials with enhanced features such as high strength, resistance to temperature, wear resistance, ductility, the toughness of fracture, fatigue resistance, etc. It must be as high as possible while minimizing other parameters such as density and cost; the latter is of general concern for automotive applications and relatively cheap light aircraft $[1,2]$. Titanium alloys are used in aircraft, armor plating, naval vessels, spacecraft, and rockets due to their high tensile strength to density ratio, high corrosion resistance, high crack resistance, and capacity to resist moderately elevated temperatures without creeping [3, 4]. Titanium alloyed with aluminum, vanadium and other elements are used for these apps for a multitude of components including critical structural parts, firewalls, landing gear, exhaust ducts (helicopters) and hydraulic systems. In reality, about two-thirds of all titanium metal generated is used in motors and frames for aircraft. Titanium alloys have to be considered a much younger structural material compared to steels or aluminum alloys. In the United States, the first alloys were created in the late 1940s. Among these was the Ti-6Al-4V classic titanium alloy, which still captures a big proportion of today's aerospace applications [5, 6]. High specific strength and great corrosion resistance are the outstanding characteristics of titanium alloys. Titanium alloys are therefore discovered in aerospace applications where the combination of 
weight, strength, corrosion resistance and/or high-temperature stability of aluminum alloys, high-resistance steels or super alloys based on nickel is insufficient [7].

Pure elements do not have properties that make it able to resist forces and chemical attacks so that they need to integrate with other elements to balance their physical and mechanical properties. Composite materials are materials fabricate with two or more constituent materials with different physical or chemical properties. Combining more one element produces a material with different characteristics from each individual component. Powder metallurgy technique is the best method for producing composite materials with homogeneous properties [8-10]. There are several types of particles, whiskers or fibers ceramics that can be used as reinforcement in composites (as $\mathrm{SiC}$, $\mathrm{Al}_{2} \mathrm{O}_{3}$, TiC, WC and diamond) according to the required application of the materials. Ceramic reinforced particle metal matrix composites (PMMC) have many mechanical advantages over the metal matrix. Generally, PMMC's have higher strength, hardness, strength to weight ratio and in some cases have higher strength at elevated temperatures. This improved the economical aspect of the product since manufacturing is possible with conventional tooling. Therefore, it is important to investigate the mechanical and metallurgical properties of such composites, specifically wear behavior. Alumina has high hardness, good stability, high oxidation capacity, very low friction coefficient (high wear resistance), and low bending stress [11-13]. Addition of alumina with other materials, from metals, intermetallics or ceramics, forming composite materials can improve alumina's mechanical properties $[14,15]$.

The primary objective of this research is replacing vanadium with molybdenum as a beta stabilizer material and studying the effect of sintering temperature on the densification of the prepared composites. Also, investigation of the effect of alumina nanoparticles content on the density, chemical composition, composites microstructure, hardness, and wear rate of the fabricated composites.

\section{Experimental Methods And Procedures}

\subsection{Materials}

As received, titanium powder with $99.8 \%$ purity and $45 \mu \mathrm{m}$ particle size (Tohotec Inc.), molybdenum powder of $100 \mu \mathrm{m}$ particle size (dop. turkey), and aluminum oxide powder of $200 \mathrm{~nm}$ particle size (Zircar Co. LTD) are used as a raw materials to prepare a Ti matrix composite suitable for dental applications. Different mixtures contain $12 \mathrm{wt} \%$ Mo and 88 wt. $\% \mathrm{Ti}$ as a matrix reinforced with $0,5,10$, and 15 wt. $\% \mathrm{Al}_{2} \mathrm{O}_{3}$, are prepared by mechanical milling for $24 \mathrm{hr} .2 \mathrm{wt}$. \% of ethanol is added as a process controlling agent. The milling process is achieved in the argon atmosphere; protect $\mathrm{Ti}$ composite from any oxidation during the milling process. The milling conditions are $100 \mathrm{rpm}$ speed by using $10 \mathrm{~mm}$ balls diameter. The ratio ball to powder is 10:1. The milled mixtures were dried at $60^{\circ} \mathrm{C}$ for 30 minutes to get rid of ethanol. The X-Ray diffraction and Scanning Electron Microscopy (SEM) are used to estimate the chemical composition and morphology of the introduced powders as well as the fabricated composites.

The prepared Ti-12Mo/x $\left(\mathrm{Al}_{2} \mathrm{O}_{3}\right)$ composites mixtures of powders are cold compacted under $600 \mathrm{MPa}$ by a uniaxial press in a die with dimensions $17 \times 12 \mathrm{~mm}^{2}$. The thickness 
of the pressed samples was $6 \mathrm{~mm}$. To determine the suitable sintering temperature of the composites, they are heated at $1300^{\circ} \mathrm{C}, 1350^{\circ} \mathrm{C}, 1450^{\circ} \mathrm{C}$, and $1500^{\circ} \mathrm{C}$ for $90 \mathrm{~min}$ soaking time. Figure 1 shows the heating cycle of the sintering process. The $1450^{\circ} \mathrm{C}$ was the best sintering temperature for the composites.

In order to prepare the composites for the microstructure evaluation, samples are ground using 400, 800, 1500, 2000, and 4000 grade SiC papers, respectively, then polished using a diamond paste of $3 \mu \mathrm{m}$ particle size. An extensive microstructural and morphological study is performed to investigate $\mathrm{Ti}, \mathrm{Mo}, \mathrm{Al}_{2} \mathrm{O}_{3}$ powders and Ti$12 \mathrm{Mo} / \mathrm{Al}_{2} \mathrm{O}_{3}$ mixtures, as well as for the Ti-12Mo/ $/ \mathrm{Al}_{2} \mathrm{O}_{3}$ sintered samples by QUANTA FEG250-EDAX Genesis scanning electron microscope. The chemical composition and phase analysis of both powders, and sintered materials are investigated by the X-ray diffraction (XRD) of the model D8 kristalloflex.

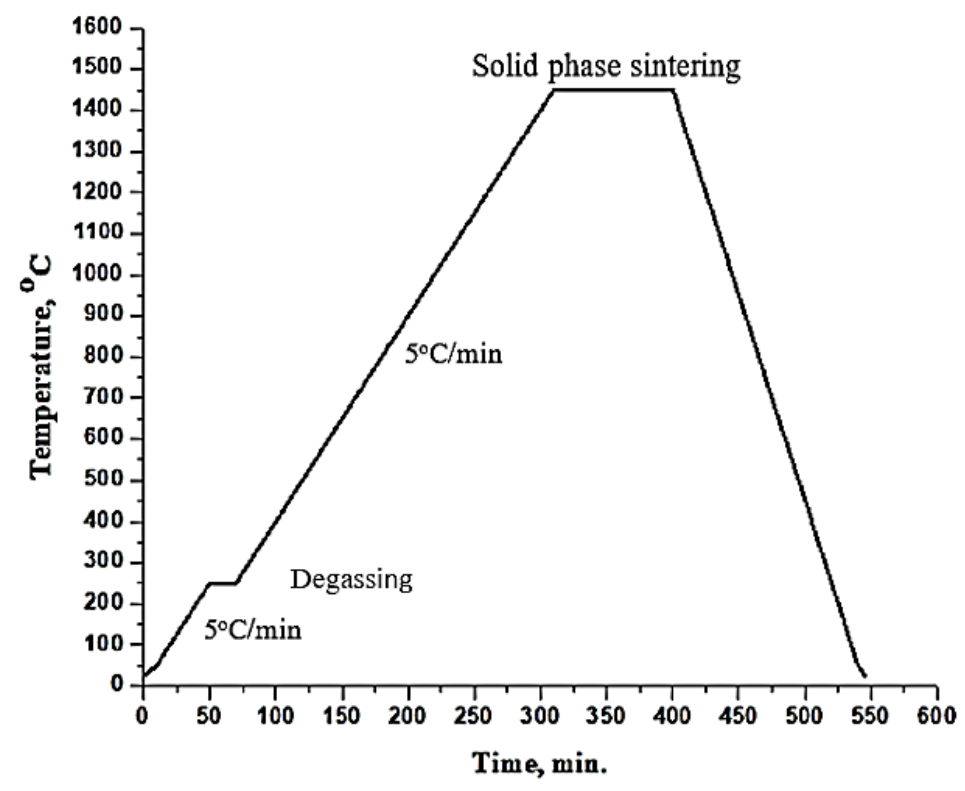

Fig. 1: Heating cycle of the sintering process.

\subsection{Physical Properties Measurements}

The densities of the bulk materials are determined by Archimedes method according to the following equation using the water as a floating liquid, as shown in the following equation [16].

$$
\rho_{\text {Arch. }}=\frac{w_{\text {air }}}{\left(w_{\text {oir }}-w_{\text {water }}\right)}
$$

Where, $\mathrm{W}_{\text {air }}$ and $\mathrm{W}_{\text {water }}$ represent the specimen weight in air and water, respectively.

\subsection{Mechanical Properties Investigation}

Vickers hardness of Ti- $12 \mathrm{Mo} / \mathrm{Al}_{2} \mathrm{O}_{3}$ sintered composites are measured using Vickers hardness tester of the model (Matsuzawa JAPAN) by applying $20 \mathrm{~kg}$ load and $15 \mathrm{sec}$ loading time at room temperature. The test is repeated for each specimen five times at different regions along the specimen cross-section, and the average of them is recorded as the value of the sample hardness. 
The wear test is carried out by the laboratory pin-on-ring method. The pin-on-ring adhesive wear test involves applying high stress between two abrasion bodies, wherein this test a rectangular pin specimen is fixed against a rotating hardened stainless steel ring. Prior to testing, the samples and ring were ultrasonically cleaned and washed in acetone. The wear behavior is studied by determining the weight loss, where specimens are weighed before and after applying the test using a scale with a sensitivity of 0.0001 gm. Each reported wear value is the average result obtained from two separate measurements.

\section{RESULTS AND DISCUSSION}

\subsection{Powder Characterization}

The morphology of titanium, molybdenum, nano-alumina, and the milled $\mathrm{Ti}-12 \mathrm{Mo} / 15$ wt. $\% \mathrm{Al}_{2} \mathrm{O}_{3}$ nano-composite powders are shown in figure 2 (a, b, c and d), respectively. It is clear from SEM that the size of the powders are in the range from 2-5 $\mu \mathrm{m}$. Different shapes of particles are detected, the first is the irregular shape for $\mathrm{Ti}$, the rod-like shape for Mo particles, and a flakey for the $\mathrm{Al}_{2} \mathrm{O}_{3}$. As a result of continuous mechanical milling for $24 \mathrm{hr}$., the particle size composite mixture is reduced to a nano-scale, less than $100 \mathrm{~nm}$ as shown in figure 2 (d).

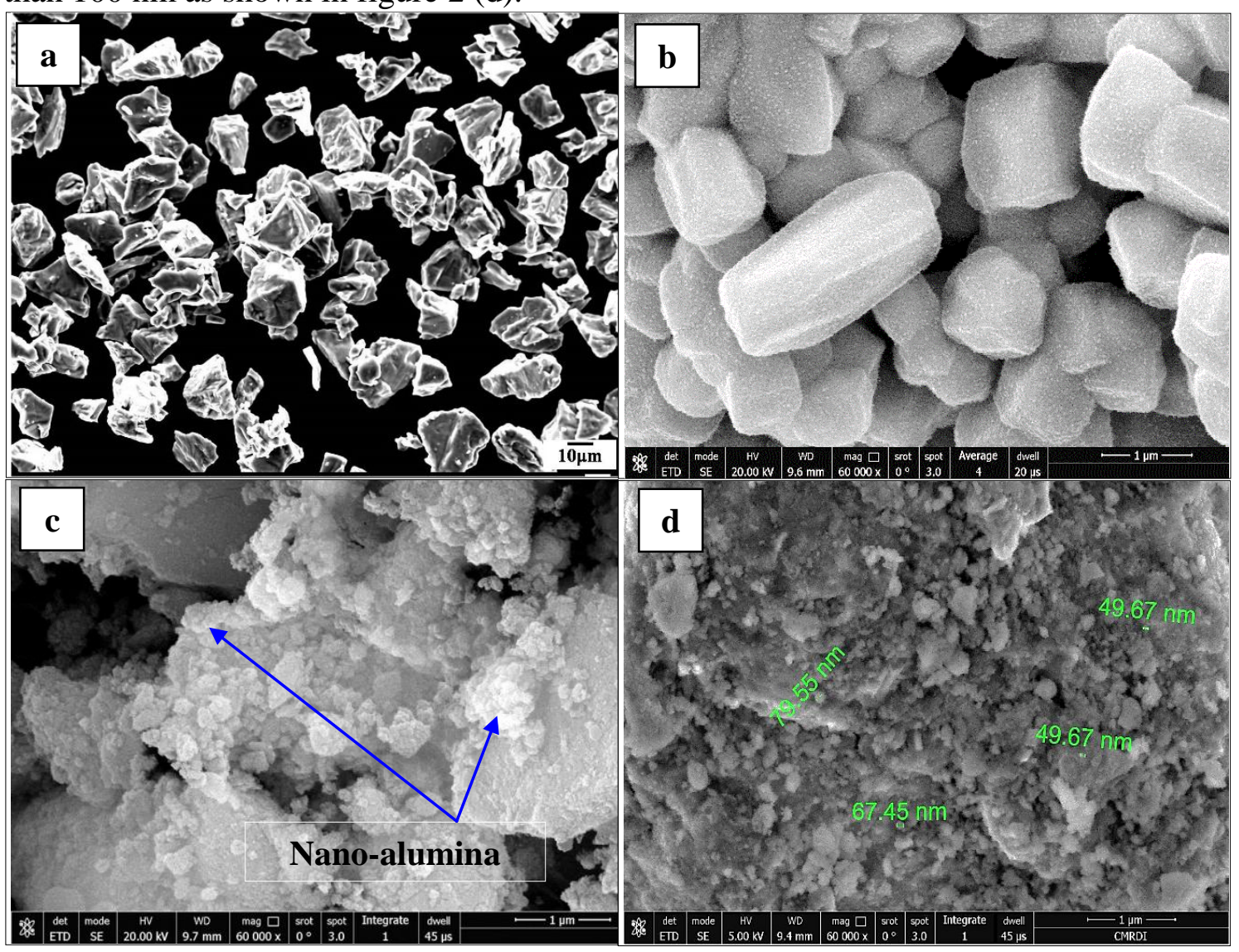

Fig. 2: SEM of the as received powders (a) Titanium, (b) Molybdenum, (c) Nanoalumina, and (d) $15 \mathrm{wt}$ \% $\mathrm{Al}_{2} \mathrm{O}_{3}$ powder composite. 


\subsection{Sintered Composites Characterizations}

\subsubsection{Density measurement}

The relative density of the Ti- $12 \mathrm{Mo} / \mathrm{x} \mathrm{Al}_{2} \mathrm{O}_{3}$ nano-composites is the percentage of the sintered density of the composites to their theoretical density of the mixed powders. Figure 3 shows the effect of reinforcing Ti matrix with 12Mo and different percentages of $\mathrm{Al}_{2} \mathrm{O}_{3}$ up to $15 \mathrm{wt}$. \% on the relative density. It was observed that Ti-12Mo without any alumina achieved relatively higher densities of $99.4 \%$. The density of Ti-12Mo was decreased by increasing the amount of $\mathrm{Al}_{2} \mathrm{O}_{3}$. For instance, $5 \mathrm{wt} \% \mathrm{Ti}-12 \mathrm{Mo} / \mathrm{Al}_{2} \mathrm{O}_{3}$ was found to be 98.9 pct dense and it decreased slightly to $97.8 \%$ for $10 \mathrm{wt} \% \mathrm{Ti}$ $12 \mathrm{Mo} / \mathrm{Al}_{2} \mathrm{O}_{3}$ and to 97.2 for $15 \mathrm{wt} \% \mathrm{Ti}-12 \mathrm{Mo} / \mathrm{Al}_{2} \mathrm{O}_{3}$. Decreasing the density of the Ti12Mo nano-composite matrix with increasing the $\mathrm{Al}_{2} \mathrm{O}_{3}$, may be due to more than one reason that summarizes in the lower density of the $\mathrm{Al}_{2} \mathrm{O}_{3}$ than that of Ti-12Mo matrix, and poor wettability of $\mathrm{Al}_{2} \mathrm{O}_{3}$ as a ceramic material with both $\mathrm{Ti}$ and $\mathrm{Mo}$, which increases the chance for pore formation on the interface between $\mathrm{Al}_{2} \mathrm{O}_{3}$ particles and $\mathrm{Ti}$ matrix, that decreases the densification.

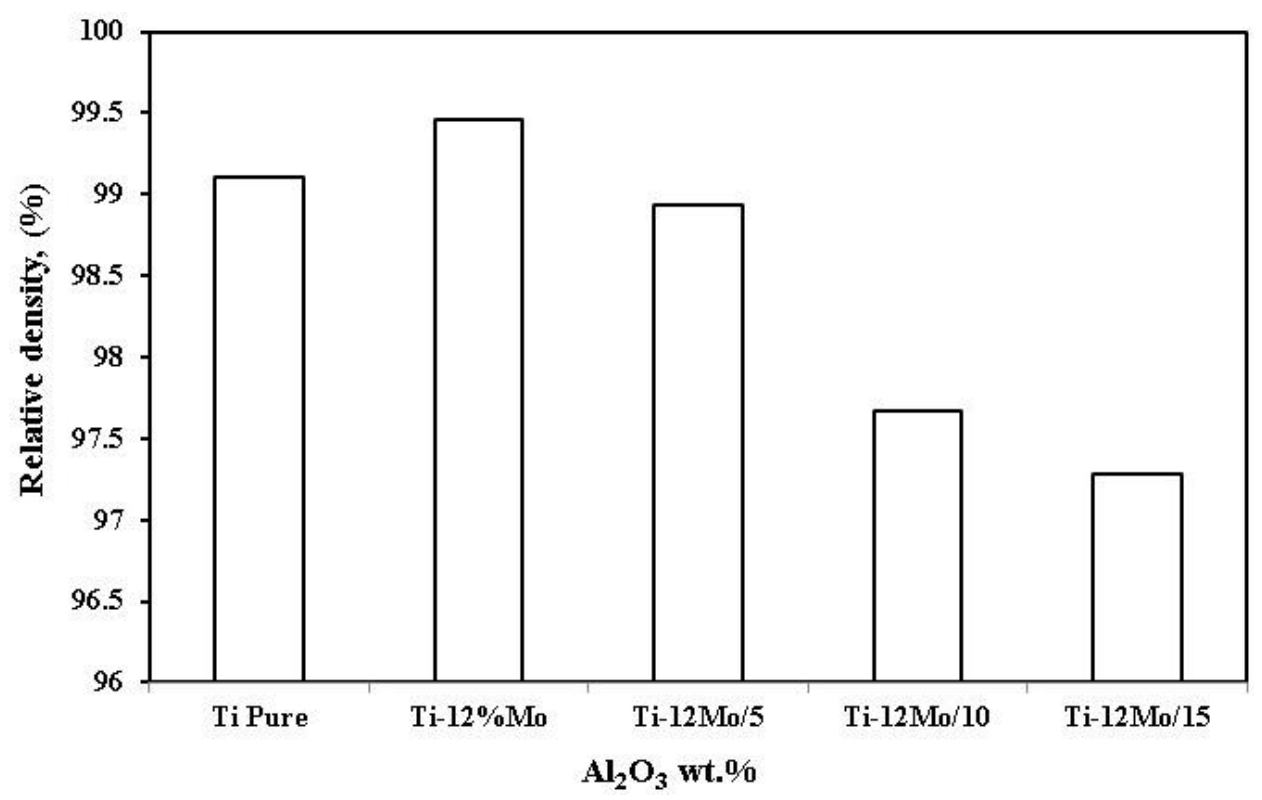

Fig. 3: Effect of $\mathrm{Al}_{2} \mathrm{O}_{3}$ percent on Ti-12Mo composite density.

\subsubsection{X-Ray Diffraction Analysis}

The purity of the used raw materials, which are $\mathrm{Ti}, \mathrm{Mo}$, and $\mathrm{Al}_{2} \mathrm{O}_{3}$ powders, are checked by the XRD analysis. As shown in figure 4 (a), no phases rather than Ti, Mo, and $\mathrm{Al}_{2} \mathrm{O}_{3}$ are detected, which prove that the used raw materials have high purity. Besides detecting of purity of the received raw materials, their crystal structures were evaluated. The analysis emphasizes that the Ti has Hcp crystal structure, Mo has a $\mathrm{BCC}$, and $\mathrm{Al}_{2} \mathrm{O}_{3}$ has a rhombohedral crystal structure.

On the other hand, to detect the interaction between the different elements after the mixing process for $24 \mathrm{hr}$., and during the sintering process, the composite materials also checked by the XRD analysis. Figure 4 (b) shows the XRD patterns of the mixtures (Ti- 
$12 \mathrm{Mo}$, and Ti-12Mo/15 wt. $\% \mathrm{Al}_{2} \mathrm{O}_{3}$ ) and the fabricated Ti-12Mo/15 wt. $\% \mathrm{Al}_{2} \mathrm{O}_{3}$. As shown in figure 4 (b) no any new chemical compositions are detected after the mixing and sintering processes. Owing to the milling and sintering in an inert atmosphere.

The Peak broadening gives an indication of the particle size, where the wider the diffraction peak, the smaller the particle size [17]. Comparing the width of the peaks of the pure elements, and the composites after milling and sintering, it can be seen that the peaks broadening after milling and sintering are wider than the peak broadening of the used materials, which means decreasing the particles size after milling.
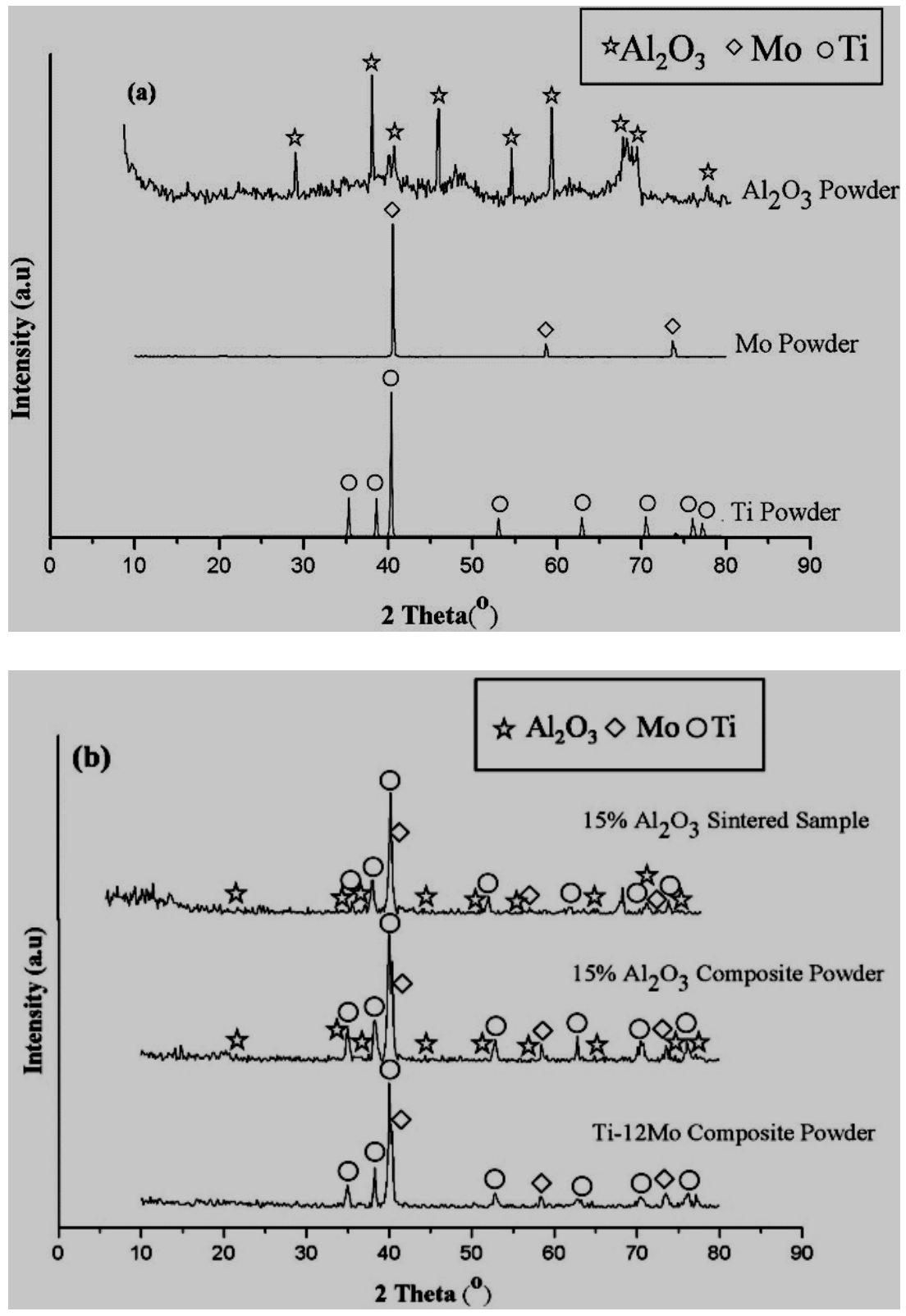

Fig. 4: XRD patterns of (a) Ti, Mo, and $\mathrm{Al}_{2} \mathrm{O}_{3}$ powders raw materials, and (b) Ti12Mo, $\mathrm{Ti}-12 \mathrm{Mo} / 15 \mathrm{wt}$. $\% \mathrm{Al}_{2} \mathrm{O}_{3}$ nano-composites powder mixture, and $\mathrm{Ti}$ 12Mo/15 wt. \% $\mathrm{Al}_{2} \mathrm{O}_{3}$ sintered nano-composite. 


\subsubsection{Composite Microstructure}

Figure 5 shows the SEM images of the manufactured pure titanium, Ti-12Mo, and Ti$12 \mathrm{Mo} / \mathrm{x} \mathrm{Al}_{2} \mathrm{O}_{3}$ composites ( $\mathrm{x}=5,10$ and 15 wt. \%). It can be observed from image (a) that the pure Ti has $(\alpha)$ phase, while the microstructure of the Ti-12Mo nano-composite exhibits two phases, which are $\alpha(\mathrm{Ti})$ and $\gamma(\mathrm{Mo})$ phases. This means that the solubility between titanium and molybdenum is limited. An excellent interface between the particles of $\mathrm{Ti}$ and Mo is clear from image (b), also a good distribution of Mo in the Ti matrix. A rim is formed as a result of the polishing process. By reinforcing Ti-12Mo matrix nano-composite with nano- $\mathrm{Al}_{2} \mathrm{O}_{3}$, changes on the microstructure, where the lamellar structure disappeared. Also, porosities and agglomerations of the nano- $\mathrm{Al}_{2} \mathrm{O}_{3}$ have occurred in the composites that contain alumina percentages over than 5 wt. $\%$. The creation of pores may be due to the poor wettability between alumina, molybdenum and the titanium matrix [18].

\subsection{Mechanical Properties}

\subsubsection{Hardness Measurement}

Figure 6 shows the hardness of the Ti-12Mo and $\mathrm{Al}_{2} \mathrm{O}_{3}$ reinforced Ti-12Mo nanocomposites at room temperature, compared to pure Ti. The figure shows that the hardness of the pure titanium is improved by reinforcing with $12 \mathrm{Mo}$ and $\mathrm{Al}_{2} \mathrm{O}_{3}$ up to 5 wt. $\%$.

The results illustrated that the addition of $12 \mathrm{wt}$. \% Mo to the pure titanium increases the hardness from 320 to 440 with a percentage of $37.5 \%$. On the other hand, it increases from 440 to 594 with a percentage of $35 \%$ because of reinforcing it with $5 \mathrm{wt}$. $\% \mathrm{Al}_{2} \mathrm{O}_{3}$. Not only the high hardness of both $\mathrm{Mo}$ and $\mathrm{Al}_{2} \mathrm{O}_{3}$ are the main factor that leads to enhances the hardness of pure $\mathrm{Ti}$, but also the excellent interface between Mo and $\mathrm{Ti}$, good distribution of $\mathrm{Mo}$ and $\mathrm{Al}_{2} \mathrm{O}_{3}$, and the ultra-fine particle size of them that have a great effect. In addition, the selection of suitable compaction pressure, sintering temperature, and sintering time play an important role. Regardless of the decreasing in the hardness of $\mathrm{Ti}-12 \mathrm{Mo} / \mathrm{Al}_{2} \mathrm{O}_{3}$ composite at percentages higher than $5 \mathrm{wt}$. $\%$, yet it is still greater than that Ti-Mo composite. the agglomeration of $\mathrm{Al}_{2} \mathrm{O}_{3}$ nano-particles and the formation of the pores by increasing the $\mathrm{Al}_{2} \mathrm{O}_{3}$ content are the main factors that responsible for decreasing the hardness after $5 \mathrm{wt} . \%[19,20]$, due to the non-wettability between $\mathrm{Al}_{2} \mathrm{O}_{3}$ and $\mathrm{Ti}$.

\subsubsection{Wear behavior}

The wear rate of the $\mathrm{Ti}-12 \mathrm{Mo} / \mathrm{xAl}_{2} \mathrm{O}_{3}$ nano-composites at $20 \mathrm{~N}, 300 \mathrm{rpm}$, and $30 \mathrm{~min}$ is shown in figure 7 [21]. It is obvious from the results that the wear rate of pure titanium decreases by the addition of molybdenum and alumina. The incorporation of alumina into the Ti-12Mo metal matrix results in a further decrease in the wear rate. The $5 \mathrm{wt} . \%$ $\mathrm{Al}_{2} \mathrm{O}_{3}$ sample exhibits the lowest wear rate compared to the other 10 , and $15 \mathrm{wt} \%$ $\mathrm{Al}_{2} \mathrm{O}_{3}$ nano-composites. Decreasing the wear rate of the composites may be due to the high hardness of molybdenum and alumina, also may be attributed to the nano-size, good adhesion, and homogeneous distribution of $\mathrm{Al}_{2} \mathrm{O}_{3}$ in the titanium-molybdenum matrix. The slight increase in wear rate of Ti-12Mo/ $\mathrm{Al}_{2} \mathrm{O}_{3}$ nano-composites with $\mathrm{Al}_{2} \mathrm{O}_{3}$ content $>5 \%$ may be attributed to the powder agglomeration, which in turn increases the porosity [22]. 

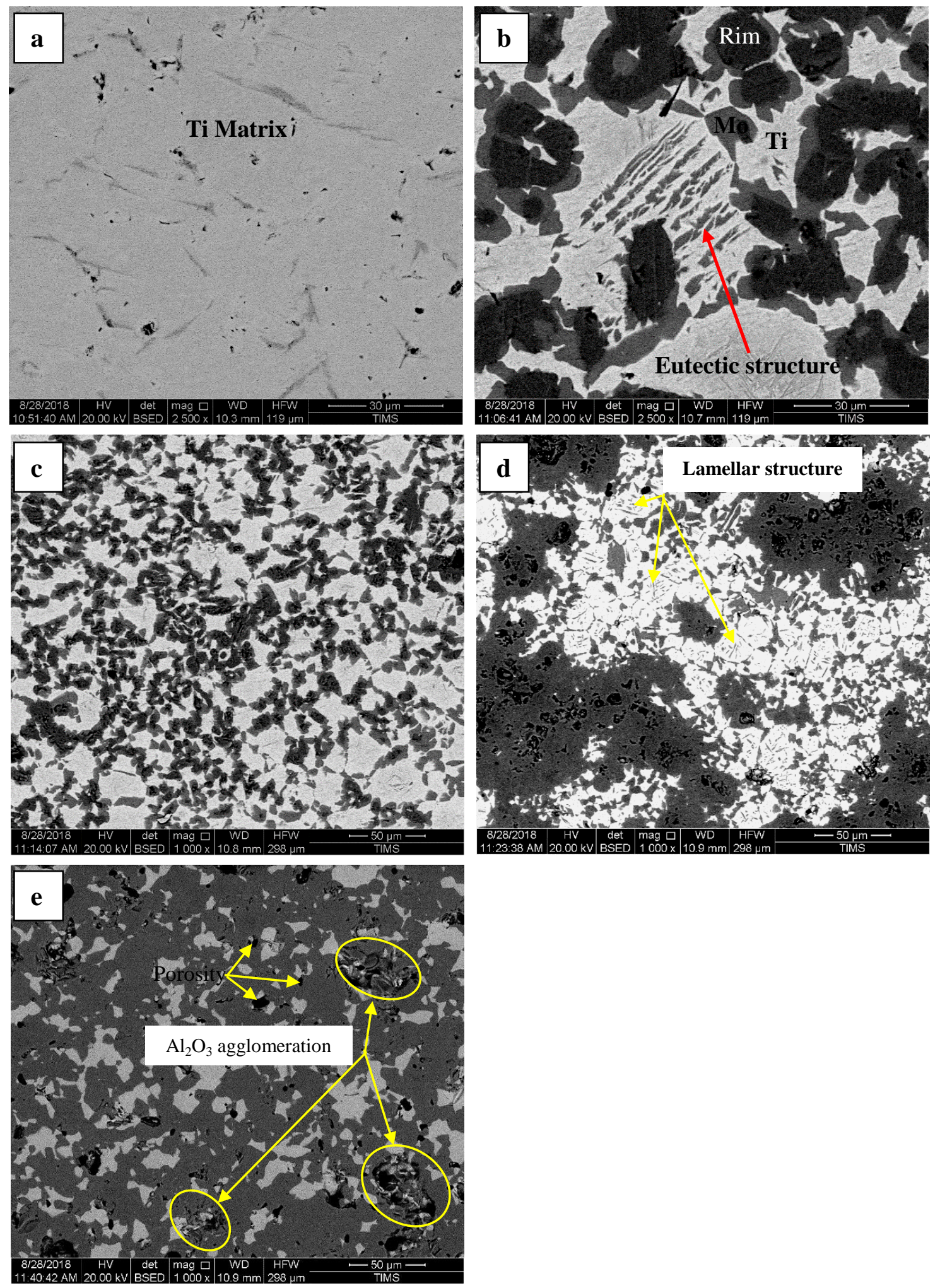

Fig. 5: SEM micrographs of (a) Ti pure, (b) Ti-12Mo, (c) Ti-12Mo/5 wt.\% $\mathrm{Al}_{2} \mathrm{O}_{3}$, (d) $\mathrm{Ti}-12 \mathrm{Mo} / 10$ wt. $\% \quad \mathrm{Al}_{2} \mathrm{O}_{3}$ and (e) $\mathrm{Ti-12Mo} / 15$ wt.\% $\mathrm{Al}_{2} \mathrm{O}_{3}$ nanocomposites. 


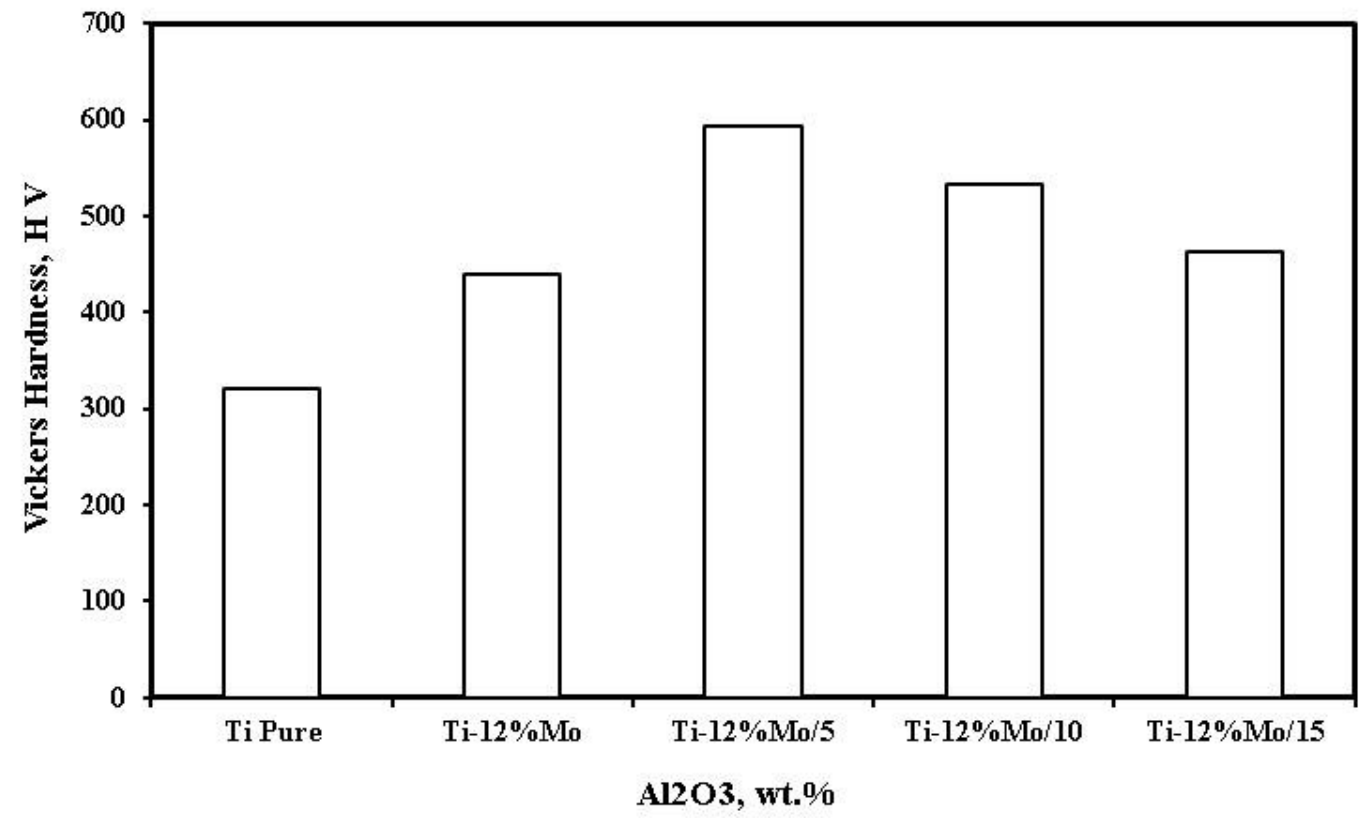

Fig. 6: Effect of $\mathrm{Al}_{2} \mathrm{O}_{3}$ nano particles content on the hardness of Ti-12Mo nanocomposites.

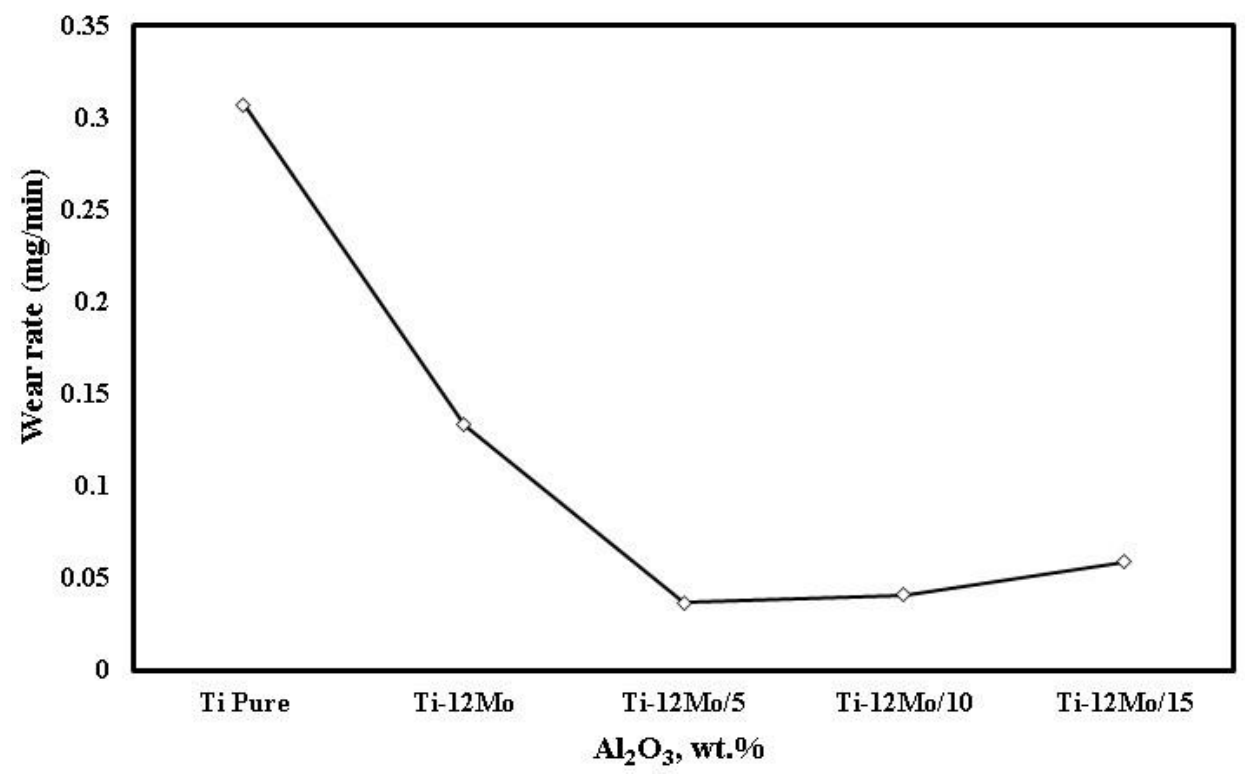

Fig. 7: Effect of $\mathrm{Al}_{2} \mathrm{O}_{3}$ content on the wear rate of the Ti-12Mo nano-composites matrix. 


\section{Conclusions}

- To improve the mechanical properties and reduce the degradation rate of titanium matrix composite, it has reinforced with $12 \mathrm{wt} . \%$ Mo with different weight percentages of the alumina that are 5, 10, and 15 wt. $\%$ of $\mathrm{Al}_{2} \mathrm{O}_{3}$.

- The suitable sintering temperature was at $1450^{\circ} \mathrm{C}$ for $90 \mathrm{~min}$ for fabrication Ti$12 \mathrm{Mo} / \mathrm{Al}_{2} \mathrm{O}_{3}$ composite.

- The SEM of the 5 wt. \% $\mathrm{Al}_{2} \mathrm{O}_{3}$ nano-composite shows an excellent distribution of both $\mathrm{Mo}$ and $\mathrm{Al}_{2} \mathrm{O}_{3}$ in the Ti matrix.

- The X-ray diffraction analysis confirmed that there are no new phases or intermetallics are formed during the sintering process.

- The relative density of pure titanium is increased by reinforcing it with 12 wt. $\%$ molybdenum and different percentages of alumina up to 5 wt. \%.

- The hardness and wear resistance of the composites take the same trend, where they are increased by adding molybdenum and different percentages of the $\mathrm{Al}_{2} \mathrm{O}_{3}$ up to 5 wt. $\%$. Regardless of decreasing the hardness and wear rate of the Ti-Mo composite after $5 \mathrm{wt}$. $\%$, they were better than those of pure titanium were.

- Ti- $12 \mathrm{Mo} / 5$ wt. $\% \mathrm{Al}_{2} \mathrm{O}_{3}$ nano-composite exhibits the acceptable mechanical property its potential application for aerospace application.

\section{ACKNOWLEDGEMENT}

The authors wish to thank the researchers and the technicians of the Central Metallurgical R\&D Institute (CMRDI) in Cairo, Egypt, and Faculty of Industrial Education, Helwan University, Cairo, Egypt for their Cooperation.

\section{REFERENCES}

[1] Froes, F. H.: "Advanced metals for aerospace and automotive use". Materials Science and Engineering: A, 184(2), pp. 119-133, (1994).

[2] Koli, D. K.; Agnihotri, G. and Purohit, R.: "Advanced aluminum matrix composites: The critical need of automotive and aerospace engineering fields". Materials Today: Proceedings, 2(4-5), pp. 3032-3041, (2015).

[3] Keohan, F. L. and Hecox B. J.: "In: Proceedings of the $21^{\text {st }}$ annual meeting of the Adhesion Society". Savannah, Georgia, 60, (1998).

[4] Bhowmik, S.; Benedictus, R.; Poulis, J. A.; Bonin, H. W. and Bui, V. T.: "Highperformance nanoadhesive bonding of titanium for aerospace and space applications". International Journal of Adhesion and Adhesives, 29(3), pp. 259-267, (2009).

[5] Eylon, D. and Seagle, S. R.: “Titanium'99: Science and technology”. St. Petersburg, pp. 866-875, (2000).

[6] Peters, M.; Kumpfert, J.; Ward, C. H. and Leyens, C.: "Titanium alloys for aerospace applications". Advanced engineering materials, 5(6), pp. 419-427, (2003).

[7] Leyens, C. and Peters, M. eds.: "Titanium and titanium alloys: fundamentals and applications". John Wiley \& Sons, (2003).

[8] Yehia, H. M.: "Microstructure, physical, and mechanical properties of the $\mathrm{Cu} /(\mathrm{WC}-$ TiC-Co) nano-composites by the electroless coating and powder metallurgy technique". Journal of Composite Materials, 53(14), pp. 1963-1971, (2019). 
[9] El-Kady, O.; Yehia, H. M. and Nouh, F.: "Preparation and characterization of $\mathrm{Cu} /(\mathrm{WC}-\mathrm{TiC}-\mathrm{Co}) / \mathrm{graphene}$ nano-composites as a suitable material for heat sink by powder metallurgy method". International Journal of Refractory Metals and Hard Materials, 79, pp. 108-114, (2019).

[10] Yehia, H. M.; Nouh, F. and El-Kady, O.: "Effect of graphene nano-sheets content and sintering time on the microstructure, coefficient of thermal expansion, and mechanical properties of ( $\mathrm{Cu} / \mathrm{WC}-\mathrm{TiC}-\mathrm{Co})$ nano-composites". Journal of Alloys and Compounds, 764, pp. 36-43, (2018).

[11] Koli, D. K.; Agnihotri, G. and Purohit, R.: "Properties and characterization of Al$\mathrm{Al}_{2} \mathrm{O}_{3}$ composites processed by casting and powder metallurgy routes". International Journal of Latest Trends in Engineering and Technology (IJLTET), 2(4), pp. 486-496, (2013).

[12] Amirkaveei, A. and Saidi, A.: "Production of $\mathrm{TiAl} / \mathrm{Al}_{2} \mathrm{O}_{3}$ and $\mathrm{TiAl} / \mathrm{Ti}_{2} \mathrm{AlC} / \mathrm{Al}_{2} \mathrm{O}_{3}$ composites by explosion synthesis". Iranian Journal of Materials Science \& Engineering, 9(4), pp. 52-8, (2012).

[13] Biao, Z .H. A. O.; Tianyu, Y. U.; Wenfeng, D. I. N. G. and Xianying, L. I.: "Effects of pore structure and distribution on strength of porous $\mathrm{Cu}-\mathrm{Sn}-\mathrm{Ti}$ alumina composites". Chinese Journal of Aeronautics, 30(6), pp. 2004-2015, (2017).

[14] Yang, Z.; Lin, J.; Wang, Y. and Wang, D.: "Characterization of microstructure and mechanical properties of $\mathrm{Al}_{2} \mathrm{O}_{3} / \mathrm{TiAl}$ joints vacuum-brazed with $\mathrm{Ag}-\mathrm{Cu}-\mathrm{Ti}+\mathrm{W}$ composite filler". Vacuum, 143, pp. 294-302, (2017).

[15] Barrena, M. I.; Matesanz, L. and de Salazar, J. G.: " $\mathrm{Al}_{2} \mathrm{O}_{3} / \mathrm{Ti6A14V}$ diffusion bonding joints using $\mathrm{Ag}-\mathrm{Cu}$ interlayer". Materials Characterization,60(11), pp.1263-1267, (2009).

[16] Selfridge, A. R.: "Approximate material properties in isotropic materials". IEEE transactions on sonics and ultrasonics, 32(3), pp. 381-394, (1985).

[17] Reda, R.; Nofal, A.; Hussein, A. H. and El-banna, E. S. M.: "Tailoring of Microstructure of Ti-6al-4v Implant Castings for Abrasive Wear Resistance". Inter. J. of Metall. \& Mater., 4, pp. 29-44, (2014).

[18] German, R. M.: "Progress in titanium metal powder injection molding". Materials, 6(8), pp. 3641-3662, (2013).

[19] El-Kady, O. and Fathy, A.: "Effect of $\mathrm{SiC}$ particle size on the physical and mechanical properties of extruded Al matrix nanocomposites". Materials \& Design (1980-2015), 54, pp. 348-353, (2014).

[20] Ma, P.; Jia, Y.; Konda Gokuldoss, P.; Yu, Z.; Yang, S.; Zhao, J. and Li, C.: "Effect of $\mathrm{Al}_{2} \mathrm{O}_{3}$ nanoparticles as reinforcement on the tensile behavior of $\mathrm{Al}-12 \mathrm{Si}$ composites". Metals, 7(9), p. 359, (2017).

[21] Mohammed, M. M.; Elkady, O. A. and Abdelhameed, A. W.: "Effect of alumina particles addition on physico-mechanical properties of AL-matrix composites". Open Journal of Metal, 3(04), p. 72, (2013).

[22] Daoush, W. M. and Elkady, O. A.: "Microstructure, physical properties and hardness of alumina short fibres/nickel matrix composites fabricated by powder technology". Journal of Composite Materials, 48(30), pp. 3735-3746, (2014). 